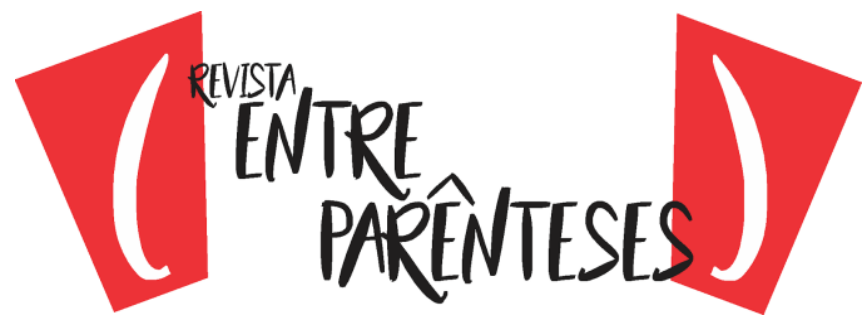

DURÃO, Fabio Akcelrud. O que é crítica literária? São Paulo: Nankin/Parábola, 2016, 118p.

\section{O QUE É CRÍTICA LITERÁRIA?}

Vicentonio Regis do Nascimento Silva ${ }^{1}$

(vicrenos@yahoo.com.br)

\begin{abstract}
Ao invés de simplesmente enumerar itens ou explicar elementos poéticos ou narrativos, a crítica os submete a uma ideia reguladora articulada pelo crítico. Aqui entra em cena sua imaginação: ao formular hipóteses, baseando-se estritamente naquilo que o texto fornece, o crítico aponta para algo inusitado, até então despercebido. Uma crítica realmente forte cola no objeto; ela reconfigura a obra de tal maneira que o seu significado passa a ser aquilo que foi enunciado e torna-se difícil imaginar qual era o seu sentido anterior à crítica (p.19-20).
\end{abstract}

Wilson Martins proclamava-se o último crítico de sua geração. Gabava-se de nunca ter integrado as "igrejinhas literárias" das quais despontavam nomes inseridos nas universidades e subscritores de colunas de jornais de grande circulação. O distanciamento então poderia proporcionar-lhe a independência para emitir seus pareceres cujos resultados, muitas vezes, fomentavam rivalidades. Dessa maneira, vislumbrando sempre os pontos de independência da constituição epistemológica da crítica literária, Fabio Durão apresenta o introdutório $O$ que é crítica literária?.

O primeiro capítulo explica como, diferenciando-se da interpretação, acrítica, ligada ao conhecimento humano e à função social, destina-se à esfera pública (portanto, a um público leitor). De acordo com o autor, a ramificação brasileira, praticada entre o século XIX e a primeira metade do XX, tem o objetivo de

\footnotetext{
${ }^{1}$ Doutor em Literatura pela Universidade Estadual de Londrina (UEL).

Revista (Entre Parênteses)

Número 7, Volume 1, 2018 - ISSN 2238-4502
} 


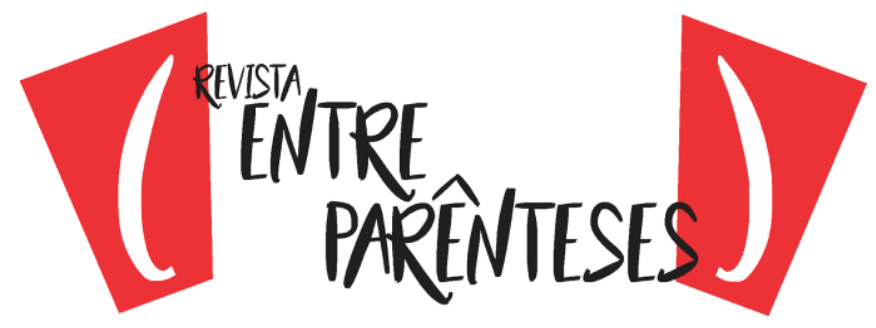

construir - ou ajudar a consolidar - a identidade nacional. Sua roupagem contemporânea vincula-a à indústria cultural, dividindo-a entre a acadêmica e a de jornal.

Quando postas lado a lado, a crítica acadêmica e a crítica de jornal deixam entrever suas fraquezas: por não ter um compromisso direto com o receptor, a crítica acadêmica é muitas vezes abstrusa e desnecessariamente difícil; a desproporção entre a produção e o uso - centenas e centenas de livros e milhares de artigos científicos não têm mais do que meia dúzia de leitores cada - não é apenas um desperdício, como também se choca com a ideia de universalidade que subjaz à ideia de cultura. Já a crítica de jornal parece estar cada vez mais incluída em uma lógica de mercado. Isso se manifesta em uma tendência para beneficiar a superficialidade, reduzir o espaço de reflexão e ignorar aquele desinteresse sem o qual crítica alguma pode ser exercida: no limite, o jornal pode fazer o comentário de um livro como se estivesse planejando sua campanha publicitária (p.1213).

A elaboração da crítica considera alguns elementos, entre eles, a boa dose de razão e a aferição de valor. Se a crítica tem função social, sentem-se seus efeitos na composição de seus enunciados que podem atribuir conceitos positivos ou negativos aos objetos analisados. O crítico também precisa saber escolher: crítica normativa ou crítica imanente? A crítica normativa estabelece regras de comparação ou toma por parâmetros outras obras ou escalas para medir o grau de relevância e inovação do volume examinado, inserindo-o em um conjunto estético. Já a crítica imanente "[...] procura julgar o texto conforme o princípio que ele parece estabelecer para si mesmo. [...] o crítico precisa perceber não apenas o que o romance, ou o poema, está querendo dizer, mas o que ele quer ser, e se consegue levar a cabo tal pretensão de maneira convincente" (p.16).

O segundo capítulo enumera quatro estudos de caso de institucionalização do conhecimento. O primeiro grupo de análises destaca que a crítica literária surge com a filosofia, especificamente em torno das nuances da linguagem, na Grécia antiga. Decreta-se um parâmetro entre a linguagem e o mundo. Fundamenta-se a crítica na verdade: de condição individual (exteriorizada 


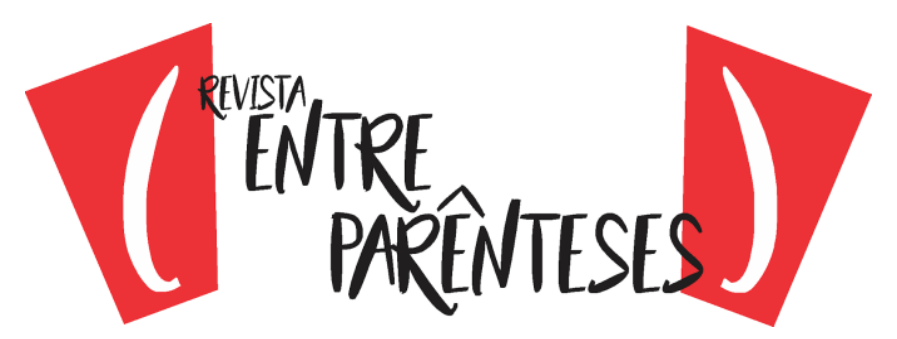

pelo oráculo, aedo/rapsodo ou rei-juiz) à coletiva (a fala individual passa a ser coletiva e, portanto, mais igualitária, pelo fato de ser dividida/discutida em grupo), criando-se um "[...] processo que pode ser chamado de desmitificação, dessacralização, ou secularização da linguagem: a passagem de uma fala de autoridade ligada ao sagrado para uma outra de natureza participativa" (p.36). 0 segundo estudo de caso debruça-se sobre a Bíblia. O autor argumenta que interpretar pressupõe aparato capaz de assimilar tanto o intratextual quanto os mecanismos de escavar e detectar pistas. Os textos exigem sistema interpretativo de modo que, dissecando as peculiaridades do antigo e do novo testamentos, recorre-se à hermenêutica medieval, ordenada em quatro níveis de sentido (Literal, Alegórico, Moral ou tropológico, Anagógico).

O terceiro estudo pondera, no século XVIII, o conceito de igualdade. Durante esse período constitui-se a crítica literária, embrião da que conhecemos atualmente.

\begin{abstract}
O espaço da crítica literária surgia como um campo a partir do qual a burguesia viu-se capaz de articular suas exigências humanísticas, em especial o princípio da universalidade da igualdade entre os homens, contra uma sociedade baseada na hierarquia, no privilégio inato de sangue da nobreza (sem, é claro, se questionar sobre o privilégio inato da herança). Um papel importante que lhe coube no período foi o de educar as camadas médias e de tornar acessível a literatura a um público mais extenso, ainda que proporcionalmente muito pequeno. Com isso, consolidava-se uma identidade de classe que, ao mesmo tempo, trazia consigo um conceito de cultura que hoje nos é mais familiar (p.62).
\end{abstract}

O século XVIII produz mudanças significativas: o julgamento literário precisa embasar-se em argumentos sólidos, sobressaindo a razão e a responsabilidade pelo que se diz em espaço público. Ainda persistem casos de autores submetidos a mecenas, entretanto, o aumento da atividade da imprensa reforça a profissionalização do escritor, consequentemente coagindo o crítico literário a buscar conhecimento específico.

O último tópico do segundo capítulo debruça-se sobre o século XIX e como nele se elabora a ideia de obra. Esta é vista menos como espelho (reflexo de 


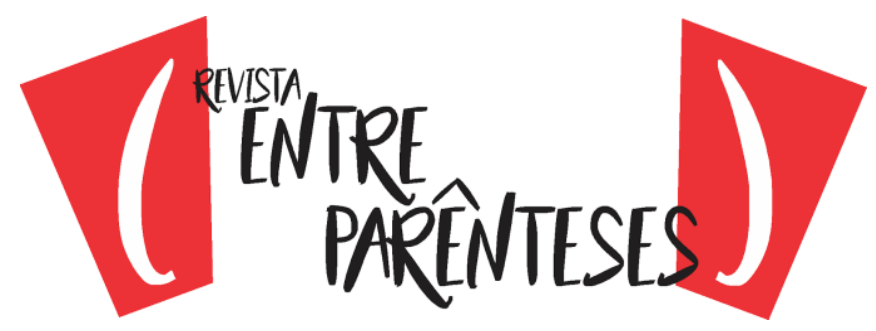

algo exterior e que ilumina a realidade) e mais como representação subjetiva (o autor concebido como gênio), saindo da imitação e assumindo o caráter de expressão:

[...] a ênfase do indivíduo criador é tanto causa quanto efeito de uma ruptura de elo aparente entre o texto e o mundo que permitirá o surgimento de uma ideia de obra como totalidade contida em si, cada vez mais regida por princípios que lhes são interiores, que ela impõe a si mesma e que consequentemente não podem mais ser ditados de fora (p.78).

Dessa maneira, o século XIX inaugura o estilo, "[...] aquele tipo de escolha e ordenamento das palavras que funciona como a assinatura do escritor, sem que ele precise escrever seu nome" (p.82). A crítica literária acompanha a ascensão de novas formas, especialmente a do romance que, surgindo no século XVIII, exige do leitor o aprofundamento nas camadas textuais mais complexas com a finalidade de detectar e explicar as ironias tão comuns nos romances românticos. O crítico então - recomenda o autor no terceiro capítulo - deve ser capaz do exercício ativo e completo de seu ofício, tornando-se "[...] competente em uma ou mais das teorias capazes de trazer inteligibilidade aos textos" (p.95). Assim, observa-se uma tecnologização do aparato crítico cujos objetivos são: 1 - Manter relação afável e, ao mesmo tempo, controversa com as demais áreas das ciências humanas (História, Sociologia, Psicanálise, Filosofia); 2 - Privilegiar o desenvolvimento interno do literário, fixando limites de independência e diálogo com outras teorias (Formalismo Russo, Estruturalismo, Pós-Estruturalismo, Desconstrução, Estética da Recepção, Crítica Feminista, Críticas de Minorias - nestas incluem-se os Estudos de Negritude e a Crítica Queer, Pós-Colonialismo e Estudos Culturais).

Adotando estilo sintético, didático e panorâmico, Fábio Durão reflete sobre a relação da Literatura com a História (ajuda a perceber as metamorfoses nas teorias e práticas literárias), Sociologia (discorre acerca da função social e dos vínculos da Literatura com a sociedade, verificando a possibilidade de a obra representar uma classe, as contradições e os desejos de liberdade, 


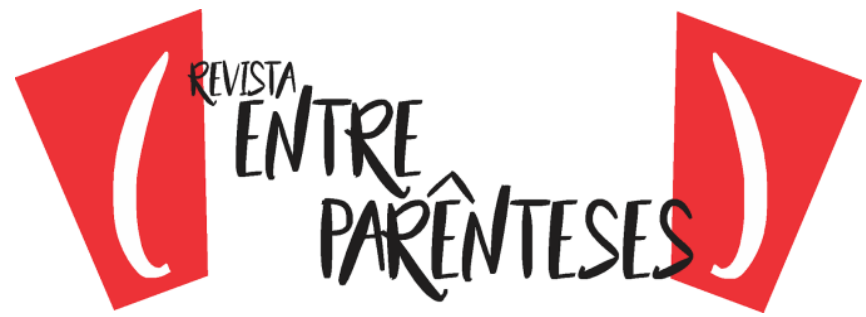

posicionamentos/ideologias de autores), Psicanálise (função psíquica do autor, das personagens, dos ambientes reais e ficcionais) e Filosofia (fornecendo e aperfeiçoando os conceitos de arte).

Além de dominar as relações com outras ciências e manifestações artísticas, o crítico também precisa analisar o diálogo da Literatura com teorias mais próximas dela sem, contudo, perder sua autonomia. Dessa maneira, indispensáveis seus esforços em busca da compreensão, por exemplo, acerca de Formalismo Russo (considerando que a moderna crítica literária começaria com ele, abdicandose de questões relacionadas à intenção do autor ou dos efeitos sobre o leitor, desmistificando-se o conceito de literariedade e apontando as diferenças da linguagem literária daquela empregada no cotidiano), Estruturalismo ("[...] sistema de combinações internas que, no entanto, pode se relacionar com outros sistemas" - $p$. 100), Pós-Estruturalismo (“[...] recusa-se a aceitar [...] limitação ao jogo textual, que agora surge como incontenível, ilimitável por qualquer aparato teórico restritivo. Toda e qualquer espécie de elemento enriquecedor de sentido passa a ser bemvindo" - p.100), Desconstrução (procura o que não é dito na obra, "[...] o excluído não é simplesmente ausente, mas é na realidade uma condição de possibilidade da própria oposição de que faz parte" - p. 101), Estética da Recepção (defende a importância do leitor, parte fundamental da leitura, já que esta "[...] não é algo passivo, uma simples decodificação de sentidos já inscritos no objeto; pelo contrário, ela tem um papel constitutivo" - p. 102).

O autor também destaca as correntes que, nas últimas décadas, ascenderam aos debates literários com interesses notadamente "políticos": Crítica Feminista ("A crítica feminista relê toda a história da literatura como relacionada ao domínio do patriarcalismo" - p. 103), os Estudos da Negritude (atacam as representações distorcidas sobre os negros que "[...] sempre ocupam uma posição subalterna, ou têm associada a si uma série de pré-conceitos formados socialmente [...]" - p. 103), a Crítica Queer (localiza "[...] nos textos consagrados do cânon impulsos sexuais latentes com o fim de questionar a normatividade sexual" - p. 103), 


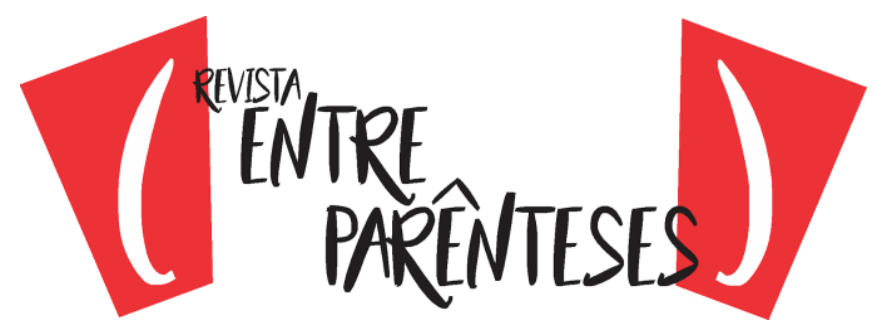

Crítica Pós-Colonial (mostra as obras literárias como veículos "[...] da dominação do Ocidente sobre o resto do mundo" - p. 104).

O último capítulo discute a atualidade da crise da crítica. $O$ autor defende a imparcialidade e a independência do ato crítico nas relações mantidas principalmente com o mercado, argumentando que ele não pode ceder aos interesses empresariais, devendo se afastar do mantra "ter-que-dizer" pela assertiva de "ter-o-que-dizer".

O que se espera do crítico hoje, então, é nada menos do que a conjunção de dois impulsos a princípio incompatíveis, a saber, conseguir esquecer-se de toda a teoria ao penetrar na obra, mas, ao mesmo tempo, lembrar-se dela para trabalhar aquilo que o texto parece exigir. $\mathrm{E}$ o interessante é que isso vale também para a teoria ou qualquer forma de metacrítica, como no caso deste livro (p.107).

A linguagem acessível na abordagem de temas culturais, assuntos literários e teorias complexas ajuda o leitor de Fabio Durão a entender melhor os liames que construíram a crítica literária, alertando-o para os pontos de convergência com outras ciências e advertindo-o da necessidade de, mesmo em diálogo com outros ramos do conhecimento ou manifestações artísticas, exigir do crítico literário formação humanística e múltipla, porém,

[...] com absoluta autonomia para configurar o objeto literário conforme sua sensibilidade ou necessidade. Não há mais amarras para o juízo crítico. Qualquer elemento da malha textual pode significar. Essa liberdade, conquistada historicamente a duras penas, tende a abolir tudo aquilo que é mediano: justamente porque tudo é possível, a repetição torna-se intolerável e cada vez mais os objetos se reduzem àqueles poucos que, de fato, fazem uso dessa liberdade para construir algo à sua altura, e os outros não conseguem se diferenciar em meio a uma multidão de tantos e tantos objetos (p.114).

Recebido em: 14/04/2018

Aceito em: 03/10/2018 